\title{
A Preliminary Analysis of the Formation of Travertine and Travertine Cones in the Jifei
} Hot Spring, Yunnan, China \author{
Yaping Liu ${ }^{\mathrm{a}, \mathrm{b}}$, Xun Zhou ${ }^{\mathrm{a},{ }^{*}}$, Bin Fang ${ }^{\mathrm{a}}$, Haiyan Zhou ${ }^{\mathrm{a}}$, Tsutomu Yamanaka ${ }^{\mathrm{c}}$ \\ a School of Water Resources and Environment, China University of Geosciences, Beijing \\ 100083, P. R. China; \\ ${ }^{\mathrm{b}}$ Graduate School of Life and Environmental Sciences, University of Tsukuba, Tsukuba \\ 305-8577, Japan; \\ ${ }^{\mathrm{c}}$ Terrestrial Environment Research Center, University of Tsukuba, Ibaraki, Tsukuba 305-8577, \\ Japan.
}

*Corresponding author: Zhou Xun, School of Water Resources and Environment, China University of Geosciences, Beijing 100083, P. R. China. E-mail: zhouxun@cugb.edu.cn

A

Abstract: The Jifei hot spring emerges in the form of spring groups in the Tibet-Yunnan geothermal zone, southwest of Yunnan Province, China. The temperatures of spring waters range from $35^{\circ} \mathrm{C}$ to $81^{\circ} \mathrm{C}$ and are mainly of $\mathrm{HCO}_{3}-\mathrm{Na} \cdot \mathrm{Ca}$ type. The total discharge of the hot spring is about $10 \mathrm{~L} / \mathrm{s}$. The spring is characterized by its huge travertine terrace with an area of about $4000 \mathrm{~m}^{2}$ and as many as 18 travertine cones of different sizes. The tallest travertine cone is as high as $7.1 \mathrm{~m}$. The travertine formation and evolution can be divided into three periods: travertine terrace deposition period, travertine cones formation period and death period. The hydrochemical characteristics of the Jifei hot spring was analyzed and compared with a local non-travertine hot spring and six other famous travertine springs. The results indicate that the necessary hydrochemical conditions of travertine and travertine cones deposition in the Jifei area are (a) high concentration of $\mathrm{HCO}_{3}{ }^{-}$and $\mathrm{CO}_{2}$; (b) about $52.9 \%$ deep source $\mathrm{CO}_{2}$ with significantly high $\mathrm{P}_{\mathrm{CO}_{2}}$ value; (c) very high milliequivalent percentage of $\mathrm{HCO}_{3}{ }^{-}$(97.4\%) with not very high milliequivalent percentage of $\mathrm{Ca}^{2+}(24.4 \%)$; and (d) a large saturation index of 
calcite and aragonite of the hot water.

Key words: Travertine, Hot spring, Thermal groundwater, Hydrochemistry, China

\section{Introduction}

The Jifei hot spring $\left(99^{\circ} 28^{\prime} 13.4^{\prime \prime} \mathrm{E}, 24^{\circ} 44^{\prime} 20.7^{\prime \prime} \mathrm{N}\right)$ (also called Zhushanxizaotang, Jifeizaotang, Shiliu or Shipen hot spring) is located on a river valley at a distance of $17 \mathrm{~km}$ from the center of Changning County $\left(99^{\circ} 16^{\prime}-100^{\circ} 02^{\prime} \mathrm{E}, 15^{\circ} 12^{\prime}-24^{\circ} 14^{\prime} \mathrm{N}\right.$ and about $\left.3774 \mathrm{~km}^{2}\right)$ in southwest of Yunnan (Fig. 1), one of the richest geothermal resources regions of China (Chen et al. 1994; Kearey and Wei 1993; Taylor and Zheng 1996). The hot spring is characterized by approximately $4000 \mathrm{~m}^{2}$ travertine landscape with as many as 18 travertine cones. This spectacular travertine landscape, especially its travertine cones is very rare in China. Several studies have been carried out on the Jifei hot spring since the 1970s (Local chronicles codification committee of Yunnan Province 1999; Chinese People's Liberation Army 1980; Liang 2000). However, these previous studies mainly focused on briefly describing hydrochemical compositions and travertine shapes. The relationship between hydrochemistry of the hot water and the travertine formation has not been investigated in detail. The travertine formation is an important hydrothermal manifestation, and may provide very useful information for the reconstitution of paleoclimate, paleoenvironment and paleohydrology (Minissale et al. 2002; Liu et al. 2003; Dilsiz et al. 2004; Veysey et al. 2008; Sun and Liu 2010). It also provides helpful information for active tectonics location diagnosis (Brogi and Capezzuoli 2009), palaeoseismological actives identification (Gürsoy et al. 2007) and more. However, the relationship between the hydrochemistry and carbonate precipitation must be determined before travertine can be confidently used as a paleoclimatic tool or so. (Liu et al. 2010). Therefore it is important to find hydrochemical controlling factors to identify origins of the travertine and travertine cones in the Jifei hot spring area.

The purpose of the present study is to give a qualitative description of the travertine and travertine cones formation process in the Jifei area based on field observation. The present study also tries to reveal the hydrochemical conditions of the travertine and travertine cone formation in the Jifei area by comparing the hydrochemical compositions of the Jifei hot spring, the Wenquanxiang hot spring $\left(99^{\circ} 41^{\prime} 45.2^{\prime \prime} \mathrm{E}\right.$, $24^{\circ} 41^{\prime} 56.6^{\prime \prime} \mathrm{N}$ ) (also named 
Changning, Xiaoshiqiao or Xiaoshijie hot spring and is $7.7 \mathrm{~km}$ far from the Jifei hot spring but has no travertine sediments) (Fig. 1), and six other travertine springs. The six travertine springs are the Huanglong spring and the Kangding thermal spring in Sichuan, China; the Baishuitai spring and the Zhongdianxiagei hot spring in Yunnan, China; the Pamukkale thermal spring in Turkey and the Mammoth thermal spring in Yellowstone National Park in 6 the US.

\section{$7 \quad$ Site description}

8 Geological and hydrogeological setting

The study area is situated in the Tibet-Yunnan geothermal zone, which is a very important geothermal zone in China (Chen et al. 1994; Kearey and Wei 1993). Administratively, the study area is attached to the Changning County of Yunnan Province, China. The Changning County has a subtropical plateau monsoon climate with annual average temperature of about $17.5^{\circ} \mathrm{C}$. The average precipitation is around $1200 \mathrm{~mm}$ and about $80 \%$ precipitation falls from May to October (Geo-Environmental Monitoring Central Station of Yunnan Province, 2004).

Stratigraphically, the rocks in this area mainly consist of sedimentary rock, magmatic rock and metamorphic rock from Cambrian to Neogene except Cretaceous. The aquifer in which the Jifei thermal groundwater occurs is the red sandstone of Neogene lacustrine deposition. Rocks underlying the Neogene lacustrine sediments include Paleozoic (Carboniferous, Devonian, Silurian, Ordovician and Cambrian) shallow marine rocks and interbedded marine and continental rocks. These settlement rocks are composed of clastic rocks including mudstone rocks, clastic rocks mixed with carbonate rocks and epimetamorphic clastic rocks including carbonate rocks, with a total thickness of $2473-5998 \mathrm{~m}$. As for the Wenquanxiang hot spring, it occurs in the Permian carbonate rock and the underlying rocks are Paleozoic carbonatite, clastic rocks with carbonate lens and epimetamorphic rock and biotite adamelite of the early Yanshan Epoch (Jurassic), with a total thickness of about $2473 \mathrm{~m}$ (Geological Bureau of Yunnan Province 1980; Chinese People’s Liberation Army 1980).

Three major tectonic systems, the middle segment of Qinghai-Tibet-Yunnan Burma Indonesia eta-type structure (which is shaped as the Greek letter “ $\eta$ ”), the Sanjiang (Nujiang, Lancangjiang and Jinsajiang rivers) radial tectonic system and the Changning-Yingpan-Yalian 
arcuate tectonic system, constitute a basic tectonic framework in this area (Fig.1) (Chinese People’s Liberation Army 1980; Geological Bureau of Yunnan Province 1980). Apianzhai fault $\left(F_{1}\right)$, Dashitoujie fault (also called Changning fault, $\left.F_{3}\right)$, Lancangjiang fault $\left(F_{4}\right)$ and Kejiehe fault $\left(\mathrm{F}_{5}\right)$ are the mainly controlling faults which divide the study area into several geological units. The $F_{1}$ and $F_{5}$ faults divide the Paleozoic sedimentary rocks and Cambrian metamorphic rocks while the $\mathrm{F}_{3}$ fault separates the Pre-Ordovician metamorphic rocks from the Cambrian metamorphic rock. Jurassic and Paleogene rocks expose along the $F_{1}$ fault. The upper Triassic rocks change significantly from one side of $F_{3}$ fault to the other. The granite of the early Yanshan Epoch mainly outcrops along the north segment of fault $F_{5}$ in the study area. Some segments of $F_{1}, F_{3}$ and $F_{5}$ faults are covered by Neogene sediments. These evidences illustrate that $F_{1}, F_{3}$ and $F_{5}$ faults were formed before Neogene, i.e. $F_{1}$ and $F_{5}$ were formed in/before Jurassic period and $\mathrm{F}_{3}$ in Triassic period. In addition, all of these major faults are characterized by multi-stage, multi-phase and multi-period processes. For instance, $\mathrm{F}_{5}$ fault exhibits compressive/compresso-shear structural features but transtensional activity characteristics have also been observed.

Hot springs occur along with these controlling faults or their secondary faults in the study area. The Jifei hot spring emerges at the potential connection part of Apianzhai fault $\left(\mathrm{F}_{1}\right)$ and the extension line of the Houshanbei fault $\left(\mathrm{F}_{2}\right)$. More than 20 hot springs occur in the Changning County. All of these hot springs are of low to medium temperature $\left(\leq 90^{\circ} \mathrm{C}\right)$ and the temperature of Jifei hot spring is the highest with up to to $81^{\circ} \mathrm{C}$ (Local chronicles codification committee of Yunnan Province 1999). Zhou et al. (1995) performed a data statistical analysis of several thermal springs in west Yunnan region. It revealed a far weaker hydrothermal activity in the study area's geological unit than in that of Tengchong in which recent volcanic activity occurred, i.e. the magma pocket in the geological unit of the study area is small or absent. Therefore, we can infer that the Jifei hot spring is restricted to faults. These faults provide a high-permeability flow path that allows deep circulation of meteoric water.

Description of the Jifei hot spring

The Jifei hot spring occurs in the form of spring groups in the Jifei canyon. The elevations of 12 vents (Fig.2) range from 1138 to $1206 \mathrm{~m}$ with a temperature ranging between $35^{\circ} \mathrm{C}$ and $81^{\circ} \mathrm{C}, \mathrm{pH}$ from 6.77 to 7.27 , and the total discharge speed of the hot springs is about 
$10 \mathrm{~L} / \mathrm{s}$. A travertine terrace (Fig. 2) outcrops on the right side of a small river in the Jifei

2 geothermal area. It is $150 \mathrm{~m}$ long, $50 \mathrm{~m}$ wide and $20 \mathrm{~m}$ high. The total area is about $4000 \mathrm{~m}^{2}$.

3 This travertine terrace trends from nearly north to south and gradually decreases in height from northwest to southeast. Fifteen travertine cones grow on the terrace and 3 separate travertine cones $\left(G_{1}, G_{2}\right.$ and $G_{3}$ in Fig. 2) deposit near the terrace. The color of the travertine terrace and travertine cones varies from grayish to black and many plants (glasses and bushes) are growing on them except on a few spots where new travertine is depositing (Fig. 4). This implies that the travertine terrace and travertine cones have stopped growing on the whole in the Jifei area.

Before analyzing the formation of travertine and travertine cones, it is necessary to first categorize the travertine cones in the Jifei area. Based on the different locations, shapes and formations, 18 travertine cones can be classified into the following 4 categories. (1) The small travertine cones which grow on the travertine terrace with height of 1-3 m. All of these travertine cones have stopped growing and no geothermal activities occur nearby them. (2) The female tower travertine cone $\left(G_{1}\right.$ in Fig. 3) which consists of two travertine cones deposited side by side. The main cone and the attached cone are respectively $4.8 \mathrm{~m}$ and $2.2 \mathrm{~m}$ high. A hot spring with water temperature of $76.5^{\circ} \mathrm{C}$ emerges under the female tower travertine cone but no new travertine formed. (3) The male tower travertine cone ( $G_{2}$ in Fig. 3) at half height of which there is a $10 \mathrm{~cm}$ thick gravel interlayer. The male tower travertine cone is the highest in the Jifei area $(7.1 \mathrm{~m})$. The gravel interlayer was probably caused by a surperflood which happened during the growth process of the travertine cone and transported gravels to the middle part of the travertine cone. (4) A single growing travertine cone ( $G_{3}$ in Fig. 3) on top of which a hot spring $\left(S_{5}\right.$, in Fig. 3$)$ emerges but with no new travertine deposition. The height of this travertine cone is $5.4 \mathrm{~m}$.

\section{Methods}

A field observation and hot water sampling were conducted during a field survey that took place on August $9^{\text {th }}$, 2007. The unstable parameters such as water temperature $(\mathrm{T}), \mathrm{pH}$ value, and electrical conductivity (EC) were measured in situ (Tables 1 and 2). Water flowing from one vent $\left(\mathrm{S}_{4}\right.$, Fig. 2) of the Jifei hot spring was collected in polyethylene bottles for hydrochemical and isotopic analysis. Another nearby hot spring but with no travertine 
formation (the Wenquanxiang hot spring) was also sampled for hydrochemical and isotopic analysis. The hydrochemical analysis (Tables 1 and 2) was performed in the Laboratory of Beijing Institute of Geological Engineering based on the China national standard methods for examination of drinking natural mineral water (GB/T 8538-1995). The carbon isotope (Table 2) of dissolved inorganic carobon (DIC) was determined in the Key Laboratory of Isotope Geology, Ministry of Land and Resources of the People’s Republic of China. For carbon isotope composition measurement, phosphoric acid method was used and the result was reported in per mil deviation relative to Vienna-PeeDee Belemnite (V-PDB) standard with an

9 accuracy of $\pm 0.2 \%$ for $\delta^{13} C_{\text {DIC }}$.

\section{Results and discussion}

Genetic analysis of travertine and travertine cones formation

The formation and evolution of travertine in the Jifei area can be divided into three main periods (Gibert et al. 2009; Liu 2005). (1) Deposition period of the travertine terrace, when numerous hot springs occurred with large flux. (2) Formation period of travertine cones (including all the small travertine cones and three separate large travertine cones), when the number of springs and total discharge flux were less than those in the first period. (3) Death period, which began when the travertine cones deposition stopped until now. The hydrothermal activity further decreased and the discharge of geothermal springs reduced considerably. During the last period, new travertine only deposits around some spring vents and travertine cliffs where hot waters flow through (Fig. 4).

The mineral composition of the travertine includes aragonite and other minerals but more than $90 \%$ of travertine consists of calcite carbonate (Jones and Renaut 2008; Pentecost 1995a). Thus the process of the travertine formation depends on the mechanism of calcite carbonate deposition. Here, the factors which influence the $\mathrm{CaCO}_{3}$ precipitation were classified as internal factors. They are the key factors for travertine sedimentation. Other factors such as weathering, erosion, etc. are classified as external factors. The external factors are only responsible for the shape of travertine. The internal factors can be further divided into 3 parts: (1) environment factors: climate, topography geology etc. (Pentecost 1995b, Brogi and Capezzuoli 2009), (2) physical and chemical properties of water: chemical composition, water temperature, flow rate and so on (Drysdale et al. 2002; Dilsiz et al. 2004) and (3) biological 
effect: biogenic encrustation, etc. Environmental and Biological factors affect travertine formation mainly through sedimentation rate and shaping. For instance, the diurnal temperatures influence the sedimentation rate of calcium carbonate by controlling the rate of $\mathrm{CO}_{2}$ efflux to atmosphere (Drysdale et al. 2003; Liu et al. 2006). The physical and chemical properties of water, i.e. hydrochemical conditions and hydrodynamic conditions, are the most important factors for travertine sedimentation. The hydrochemical conditions (for example, concentrations of $\mathrm{Ca}^{2+}, \mathrm{HCO}_{3}^{-}$and $\mathrm{CO}_{2}$ ) are factors controlling whether travertine sedimentation can occur and hydrodynamic conditions (including flow rate and thickness of flow water and so on) are factors controlling whether travertine sedimentation should occur (Zhou et al. 2010).

In the Jifei geothermal area, travertine precipitated on various landforms. For example, travertine terrace was formed on a slight gradual slope, some travertine cones grew in lowland of the river valley and some new travertine deposits on the steep travertine cliff (Fig. 4). Hydrodynamic conditions of the hot waters flowing through various landforms must be much more different. However, no matter what hydrodynamic conditions are, it is hydrochemical conditions that play an important role in causing travertine deposition in the Jifei area. Therefore, it is necessary to bring out the main hydrochemical factors for travertine and travertine cones formation in the Jifei area.

Comparison of the Jifei and the Wenquanxiang hot springs

The Wenquanxiang hot spring, a non-travertine depositing hot spring, occurs $7.7 \mathrm{~km}$ far from the Jifei hot spring (Fig. 1). The environmental factors, the climate conditions and hydrological conditions are similar in these two regions. From the geological setting, it is found that both of these two hot springs are restricted by faults and are formed by deep circulation of meteoric water. The outcrop rocks around these two hot springs are also similar. Those rocks are from Paleozoic: carbonate rock, clastic rock and epimetamorphic rock.

Hydrochemical analysis (Table 1) shows that both of the Jifei and the Wenquanxiang hot springs are of low-to-medium temperature $\left(\leq 90^{\circ} \mathrm{C}\right)$ and of $\mathrm{HCO}_{3}-\mathrm{Na} \cdot \mathrm{Ca}$ water type hot springs. The major cations are $\mathrm{Na}^{+}+\mathrm{K}^{+}$and $\mathrm{Ca}^{2+}$, accounting for $65.8 \%$ and $24.4 \%$ equivalent of the cations in the Jifei hot spring versus $64.9 \%$ and $30.7 \%$ in the Wenquanxiang hot spring. The major anions of both of these two hot springs are $\mathrm{HCO}_{3}{ }^{-}$, constituting $97.4 \%$ and $83.9 \%$ 
equivalent of the anions, respectively. The $\mathrm{pH}$ values are 6.97 and 7.36 respectively, and the TDS are $993 \mathrm{mg} / \mathrm{L}$ for Jifei and $832 \mathrm{mg} / \mathrm{L}$ for Wenquanxiang. While $\mathrm{Ca}^{2+}$ concentrations are very similar, $\mathrm{HCO}_{3}{ }^{-}$and $\mathrm{CO}_{2}$ contents in the Jifei hot spring are significantly higher than those in the Wenquanxiang hot spring.

The calcite carbonate sedimentation equation is expressed as follows:

$$
\mathrm{Ca}^{2+}+2 \mathrm{HCO}_{3}^{-} \leftrightarrow \mathrm{H}_{2} \mathrm{O}+\mathrm{CO}_{2} \uparrow+\mathrm{CaCO}_{3} \downarrow
$$

Based on this equation, it can be stated that calcium carbonate precipitation is related to $\mathrm{CO}_{2}$ outgassing. In other words, if the concentration of dissolved carbon dioxide is less than the dissolved carbon dioxide regulating equilibrium, then precipitation of calcium carbonate will occur. Thus the $\mathrm{CO}_{2}$ is a very important factor for travertine formation. Previous studies (Clark and Fritz 1997, Liu et al 2003) pointed out that $\delta^{13} \mathrm{C}$ value is about $-7 \%$ for atmospheric $\mathrm{CO}_{2}$, around $-25 \%$ (ranges from $-16 \%$ to $-28 \%$ ) for $\mathrm{CO}_{2}$ formed by soil organisms or modern biological carbon and almost nil for $\mathrm{CO}_{2}$ formed by Marine limestone. According to Deines et al. (1974), $\delta^{13} \mathrm{C}$ values of carbonate and $\mathrm{CO}_{2}$ gas are related to absolute temperature as follows:

$$
\delta^{13} \mathrm{C}_{\mathrm{HCO}_{3}}-\delta^{13} \mathrm{C}_{\mathrm{CO}_{2}}=-4.54+1.099 \times 10^{6} / \mathrm{T}^{2}
$$

As the temperature of hot spring water in the Jifei area is $79{ }^{\circ} \mathrm{C}(352.15 \mathrm{~K})$ and $\delta^{13} \mathrm{C}_{\mathrm{HCO}_{3}}{ }^{-}$ $\left(\delta^{13} \mathrm{C}_{\mathrm{DIC}}\right)=-7.6 \%$, the $\delta^{13} \mathrm{C}_{\mathrm{CO}_{2}}$ value is $-11.92 \%$ when isotopic exchange reaches equilibrium. However, this value doesn’t belong to any values range or close to any value of $\delta^{13} \mathrm{C}_{\mathrm{CO}_{2}}$ mentioned above. The probable reason is that the $\mathrm{CO}_{2}$ in the Jifei area originates from at least two sources. Considering the geological setting, the deep fault provides a convenient route for gas ascension from deep earth, i.e. the mantle is one source of $\mathrm{CO}_{2}$. In addition, the $\mathrm{CO}_{2}$ coming from metamorphic carbonate rock shouldn't be neglected as temperatures probably reach the calcite decomposition temperature threshold $\left(400{ }^{\circ} \mathrm{C}\right)$ in the deep geothermal reservoir. If there is only one geothermal reservoir, the various temperatures $\left(35-81^{\circ} \mathrm{C}\right)$ of different spring vents in the Jifei geothermal area indicate a phenomenon of mixing between shallow cold groundwater and deep thermal groundwater. In other words, the hot water was mixed by the shallow cold groundwater dissolving a lot of $\mathrm{CO}_{2}$ gas from soil organisms before 
it issued as hot spring. In short, the solution $\mathrm{CO}_{2}$ in the Jifei hot spring water comes from deep source (mantle and metamorphic carbonate rock) and shallow source (soil organisms).

If we suppose that the ratio of $\mathrm{CO}_{2}$ from shallow source is $\mathrm{X} \%$, the ratio from deep source is $(100-\mathrm{X}) \%$. Based on the isotope mass balance, the following equation can be obtained (Liu et al 2000):

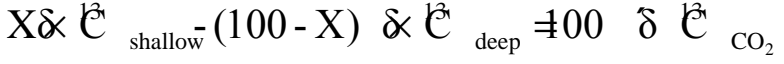

A $\delta^{13} \mathrm{C}$ of $-5.5 \pm 0.5 \%$ for mantle carbon was used to clarify $\mathrm{CO}_{2}$ source in the Huanglong Ravines, Sichuan, China (Yoshimura et al. 2004). In this study, the mean value

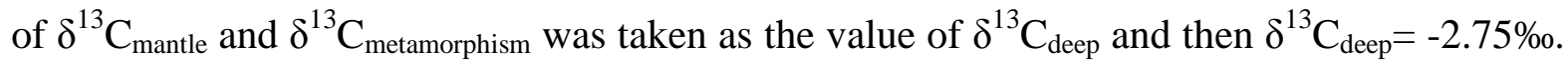
The $\delta^{13} \mathrm{C}$ value of $\mathrm{CO}_{2}$ from soil organism or modern biological carbon was used as $\delta^{13} \mathrm{C}_{\text {shallow }}$ value and then $\delta^{13} \mathrm{C}_{\text {shallow }}=-25 \%$. The calculated results show that about $47.1 \%$ $\mathrm{CO}_{2}$ comes from shallow source and about $52.9 \% \mathrm{CO}_{2}$ comes from deep source in the Jifei geothermal area. The same method was applied to estimate the $\mathrm{CO}_{2}$ source ratios in the Wenquanxiang hot spring and the estimated results are that about $30.7 \%$ and $69.3 \%$ of $\mathrm{CO}_{2}$ comes from deep source and shallow source, respectively. It should be noted that maybe more $\mathrm{CO}_{2}$ comes from deep source in the Jifei geothermal area as influencing factors of carbon isotopes widely exist. Use of inert gases (He, Ar etc.) isotopes to further determine the source of $\mathrm{CO}_{2}$ is necessary and should be carried out in the future works.

Five kinds of minerals were chosen to analyze their saturation index (Fig. 5) by using PHREEQC-2 program, and the results indicate that the calcite $\left(\mathrm{CaCO}_{3}\right)$, aragonite $\left(\mathrm{CaCO}_{3}\right)$, dolomite $\left(\mathrm{CaMg}\left(\mathrm{CO}_{3}\right)_{2}\right)$ of the Jifei hot water are in a saturation state and the saturation indexes for all of them are higher than 0.5. As for the Wenquanxiang hot spring, the calcite and aragonite reach saturation state, however, saturation indexes of these two minerals are less than 0.2. Combined with the difference in hydrochemical compositions in these two hot springs, it is found that the high contents of $\mathrm{HCO}_{3}{ }^{-}$and $\mathrm{CO}_{2}$ are one of the major parameters that control the travertine and travertine cones formation in the Jifei area. The source of $\mathrm{CO}_{2}$, half of which comes from deep source, as well as the high saturation indexes of calcite and aragonite mineral are also important factors of travertine and travertine cones precipiation in the Jifei geothermal area. 
Difference in hydrochemistry among the Jifei hot spring and six other travertine springs

Six famous travertine springs (Table 2) were selected to compare with the Jifei hot spring in terms of hydrochemical composition. These six travertine springs are the Huanglong spring (Yoshimura et al. 2004, Lu et al. 2000) and the Kangding thermal spring (Liu et al. 2000) in Sichuan, China; the Baishuitai spring (Liu et al. 2003) and the Zhongdianxiagei hot spring (Liu et al. 2000) in Yunnan, China; the Pamukkale thermal spring in Turkey (Dilsiz 2005) and the Mammoth thermal spring in the Yellowstone national park in the US (McCleskey et al. 2004). Huge travertine landscape can be found around all of these springs, and their carbon dioxide mainly comes from the deep earth. However, travertine cones formation occurred only in the Jifei area except one travertine cone formed near the Mammoth thermal spring (Zhou et al, 2010).

Hydrochemical and isotopic data of these seven travertine springs are shown in Table 2. Note that these springs temperatures are $\leq 90^{\circ} \mathrm{C}$ and the TDS values are $\leq 3000 \mathrm{mg} / \mathrm{L}$. In other words, the travertine is a formation of low-to-moderate temperature geothermal system with low mineralization. The hydrochemical compositions of these spring waters are plotted in a Piper diagram (Fig. 6). Data plots in the diagram demonstrate that these travertine springs water are rich in $\mathrm{HCO}_{3}{ }^{-}$, lack of $\mathrm{Cl}^{-}$and are of $\mathrm{HCO}_{3}{ }^{-}$type water. The $\mathrm{Ca}^{2+}$ and/or $\mathrm{Na}^{+}$cation are dominant for all the spring waters studied and the concentrations of $\mathrm{SO}_{4}{ }^{2-}$ are quite high for the Pamukkale and the Mammoth hot waters which have higher values of TDS than the others'. The difference in hydrochemistry of the travertine springs is probably due to the rock type from which the waters issue (Appelo and Postma, 2005). The milligram equivalent percentages of $\mathrm{Ca}^{2+}$ and/or $\mathrm{HCO}_{3}{ }^{-}$are high in all of these springs (Fig. 7) and at least one of them is especially high, not less than 56.3\%. The high contents of $\mathrm{Ca}^{2+}$ and/or $\mathrm{HCO}_{3}{ }^{-}$ constitute the necessary material conditions for travertine formation. For the Jifei hot spring, $\mathrm{Na}^{+}$is the first major cation accounting for $61.5 \%$ equivalent to the sum of cations and $\mathrm{Ca}^{2+}$ only accounts for $24.4 \% . \mathrm{HCO}_{3}{ }^{-}$is the major anion and the milliequivalent percentage is 97.4\%. Thus, the very high milliequivalent percentage of $\mathrm{HCO}_{3}{ }^{-}$with not very high milliequivalent percentage of $\mathrm{Ca}^{2+}$ is probably the necessary hydrochemical condition for the formation of travertine cones. The chemistry of the Zhongdianxiagei hot spring water is very similar to the Jifei hot spring water (Fig. 6) but no travertine cone was found around the 
1 Zhongdianxiagei hot spring. Its milliequivalent percentage of $\mathrm{HCO}_{3}^{-}$is $91.7 \%$ and $\mathrm{Ca}^{2+}$ is $30.7 \%$. There is yet a significant difference in $\delta^{13} \mathrm{C}_{\text {DIC }}$ values between the Jifei and the Zhongdianxiagei springs (-7.6\% versus $0.9 \%$ o). In other words, the $\mathrm{CO}_{2}$ sources are different in these two areas. The calculated $\mathrm{CO}_{2}$ in the Jifei geothermal area shows that $47.1 \%$ comes from shallow source (soil organisms or modern biological carbon) and about $52.9 \%$ comes from deep source (mantle and metamorphism). Liu et al. (2000) pointed out that the $\mathrm{CO}_{2}$ of the Zhongdianxiagei hot spring is mainly from deep source $(66 \%$ is limestone metamorphic $\mathrm{CO}_{2}$ and $34 \%$ is magmatic $\mathrm{CO}_{2}$ ). Therefore, the source of $\mathrm{CO}_{2}$ is also very important for the travertine cones formation.

The $\mathrm{CO}_{2}$ pressures $\left(10^{-1.8} \sim 10^{+0.52} \mathrm{~atm}\right)$ of these 7 springs are very high, and they are much higher than that of atmosphere $\left(10^{-3.5} \mathrm{~atm}\right)$ and in the Pammukkale geothermal area, the pressure of $\mathrm{CO}_{2}$ in the spring water even reaches to thousands of times of the atmospheric pressure. The high $\mathrm{P}_{\mathrm{CO}_{2}}$ value shows that strong gas-water-rock interaction effect and boiling phenomena etc. exist under land surface. This high pressure of $\mathrm{CO}_{2}$ is also a very necessary condition for the travertine formation. The saturation indexes diagram of five minerals for these 7 spring water calculated with the PHREEQC-2 program (Fig. 8) shows that the saturation index of calcite floats around zero, i.e., calcite is under or near the saturation state. Aragonite and dolomite are also under or near the saturation state. Thus, the minerals of calcite, aragonite and dolomite in saturation condition are also very important controlling factors for travertine sedimentation. Especially, in the Kangding, Jifei, Mammoth and Zhongdianxiagei, the calcite and aragonite of the hot waters are in saturation state. Saturation index of calcite and aragonite in the Jifei area is larger than in the Zhongdianixiagei area, indicating that calcium carbonate is easier to deposit around the spring in the Jifei area than in the Zhongdianxiagei area. That's why although hydrochemistry of the Zhongdianxiagei and the Jifei springs is similar, travertine cones formed only in the Jifei area.

\section{Summary and Conclusion}

The Jifei hot spring occurs in the form of a spring group with temperature of $35-81^{\circ} \mathrm{C}, \mathrm{pH}$ 6.77-7.27, $993 \mathrm{mg} / \mathrm{L}$ TDS and $\mathrm{HCO}_{3}-\mathrm{Na} \cdot \mathrm{Ca}$ type water in Changning County, southwest Yunnan, China. The total flow is about $10 \mathrm{~L} / \mathrm{s}$. Local geological setting shows that the hot 
spring is restricted to faults and is developed from deep circulation of meteoric water. A $150 \mathrm{~m}$ long, $50 \mathrm{~m}$ wide and $20 \mathrm{~m}$ high travertine terrace has deposited in the Jifei geothermal area. Eighteen travertine cones with heights ranging from $1 \mathrm{~m}$ to $7.1 \mathrm{~m}$ formed near or on the travertine terrace. Based on the different locations, shapes and formations, the 18 travertine cones were classified into 4 categories: (1) Small travertine cones growing on the travertine terrace; (2) The female tower travertine cone constituted by two travertine cones growing side by side; (3) The male tower travertine cone, with a $10 \mathrm{~cm}$ gravel interlayer at half height; (4) A single growing travertine cone $\left(G_{3}\right)$ on the top of which a hot spring emerges. The whole thank an anonymous reviewer for his constructive comments to the manuscript. 


\section{References}

Appelo CAJ, Postma, D (2005) Geochemistry, Groundwater and Pollution, $2^{\text {nd }}$ Edition.

A. A. Balkema Publisher, Leiden, p649

Brogi A, Capezzuoli E (2009) Travertine deposition and faulting: the fault-related travertine fissure-ridge at Terme S. Giovanni, Rapolano Terme (Italy). Int J Earth Sci (Geol Rundsch) 98:931-947

Chen M, Wang J, Deng X (1994) Geothermal Systems in China: Formation, Characteristics and Potential Evaluation. Science Press, Beijing, p260

Chinese People's Liberation Army (1980) Report of regional hydrogeological investigation of Baoshan area, China (at 1:200,000)

Clark ID, Fritz P (1997) Environmental Isotopes in Hydrogeology. Lewis Publishers, New York, p 328

Deines P, Langmuir D and Harmon RS (1974) Stable carbon isotope ratios and the existence of a gas phase in the evolution of carbonate ground waters. Geochimi Cosmochim Acta 38:1147-1164

Dilsiz C (2005) Conceptual hydrodynamic model of the Pamukkale hydrothermal field, southwestern Turkey, based on hydrochemical and isotopic data. Hydrogeol J 14:562-572

Dilsiz C, Marques JM, Carreira PMM (2004) The impact of hydrological changes on travertine deposits related to thermal springs in the Pamukkale area (SW Turkey). Environ Geol 45:808-817

Drysdale RN, Taylor MP, Ihlenfeld C (2002) Factors controlling the chemical evolution of travertine-depositing rivers of the Barkly karst, northern Australia. Hydrol Process $16: 2941-2962$

Drysdale R, Lucas S, Carthew K (2003) The influence of diurnal temperatures on the hydrochemistry of a tufa-depositing stream. Hydrol Process 17:3421-3441

Geo-Environmental Monitoring Central Station of Yunnan Province (2004) Report of geologic hazards investigation and regionalization in Changning County, Yunnan

Geological Bureau of Yunnan Province (1980) Report of regional geological investigation of Baoshan area, China (with the scale of 1:200,000)

Gibert RO, Taberner C, Sáez A, Giralt S, Alonso RN, Edwards RL, Pueyo JJ (2009) 
Igneous Origin of $\mathrm{CO}_{2}$ in Ancient and Recent Hot-Spring Waters and Travertines from the Northern Argentinean Andes. J Sediment Res 79:554-561

Gürsoy H, Mesci BL, Piper JDA, Tatar O, Davies CJ (2007) The magnetism in tectonically controlled travertine as a palaeoseismological tool: examples from the Sicak Çermik geothermal field, central Turkey. Geol Soc 291:291-305

Jones B and Renaut RW (2008) Cyclic development of large, complex, calcite dendrite crystals in the Clinton travertine, Interior British Columbia, Cananda. Sediment Geol 203:17-35

Kearey P and Wei HB (1993) Geothermal fields of China. J Volcanol Geotherm Res 56:415-428

Liang N (2000) A broad view of the hot springs in Yunnan. People’s Publishing House of Yunnan, Kunming, p129

Liu S (2005) Geothermal resources and their utilization and protection. Chemical Industry Press, Beijing, pp310

Liu Z, Li Q, Sun H (2006) Diurnal Variations of Hydrochemistry in a Travertine-depositing Stream at Baishuitai, Yunnan, SW China. Aquat Geochem 12:103-121

Liu Z, Sun H, Lu B, Liu X, Ye W, Zeng C (2010) Wet-dry seasonal variations of hydrochemistry and carbonate precipitation rates in a travertine-depositing canal at Baishuitai, Yunnan, SW China: Implications for the formation of biannual laminae in travertine and for climatic reconstruction. Chem Geol 273: 258-266

Liu Z, Yuan D, He S, Zhang M, Zhang J (2000) Geochemical features of the geothermal $\mathrm{CO}_{2}$-Water-carbonate rock system and analysis on its $\mathrm{CO}_{2}$ sources - Examples from Huanglong Ravine and Kangding, Sichuan, and Xiage, Zhongdian, Yunnan. Science In China (Series D) 43:569-576

Liu Z, Zhang M, Li Q, You S (2003) Hydrochemical and isotope characteristics of spring water and travertine in the Baishuitai area (SW China) and their meaning for paleoenvironmental reconstruction. Environ Geol 44:698-704

Local chronicles codification committee of Yunnan Province (1999) The chronicles of hot springs, volume 25. In: The local chronicles of Yunnan Province. Yunnan people's publishing house, Kunming 
Lu G, Zheng C, Donahoe RJ, Lyons WB (2000) Controlling processes in $\mathrm{CaCO}_{3}$

precipitating stream in Huanglong Natural Scenic District, Sichuan, China, J Hydrol 230:34-54

McCleskey RB, Ball JW, Nordstrom DK, Holloway JM, Taylor HE (2004) Water-Chemistry Data for Selected Hot Springs, Geysers, and Streams in Yellowstone National Park, Wyoming, 2001-2002. USGS Open-File Report 2004-1316

Minissale A, Kerrick DM, Magro G, Murrell MT, Paladini M, Rihs S, Sturchio NC, Tassi F, Vaselli O (2002) Geochemistry of Quaternary travertines in the region north of Rome (Italy): structural, hydrologic and paleoclimatic implications. Earth Planet Sci Lett 203:709-728

Pentecost A (1995a) Geochemistry of carbon dioxide in six travertine-depositing waters of Italy. J Hydrol 164:263-278

Pentecost A (1995b) The Quaternary Travertine Deposits of Europe and Asia Minor. Quat Sci Rev 14:1005-1028

Sun H, Liu Z (2010) Wet-dry seasonal and spatial variations in the $\delta^{13} \mathrm{C}$ and $\delta^{18} \mathrm{O}$ values of the modern endogenic travertine at Baishuitai, Yunnan, SW China and their paleoclimatic and paleoenvironmental implications. Geochim Cosmochim Acta 74:1016-1029

Taylor A, Zheng L (1996) Geothermal Resources in China. Bob Lawerence \& Associates, Alexandria

Veysey J, Fouke BW, Kandianis MT, Schickel TJ, Johnson RW, Goldenfeld N (2008) Reconstruction of Water Temperature, $\mathrm{pH}$, and Flux of Ancient Hot Springs from Travertine Depositional Facies. J Sediment Res 78:69-76

Yoshimura K, Liu Z, Cao J, Yuan D, Inokura Y, Noto M (2004) Deep source $\mathrm{CO}_{2}$ in natural waters and its role in extensive tufa deposition in the Huanglong Ravines, Sichuan, China. Chem Geol 205:141-153

Zhou Z, Xiang C, Zhao J (1995) Characteristics of geothermal field in west Yunnan. Earthq Res 18:41-48

Zhou X, Jin X, Liang S, Shen Y, Zhang H (2010) Special Topics on Groundwater Sciences. Geological Publishing House, Beijing, p202 


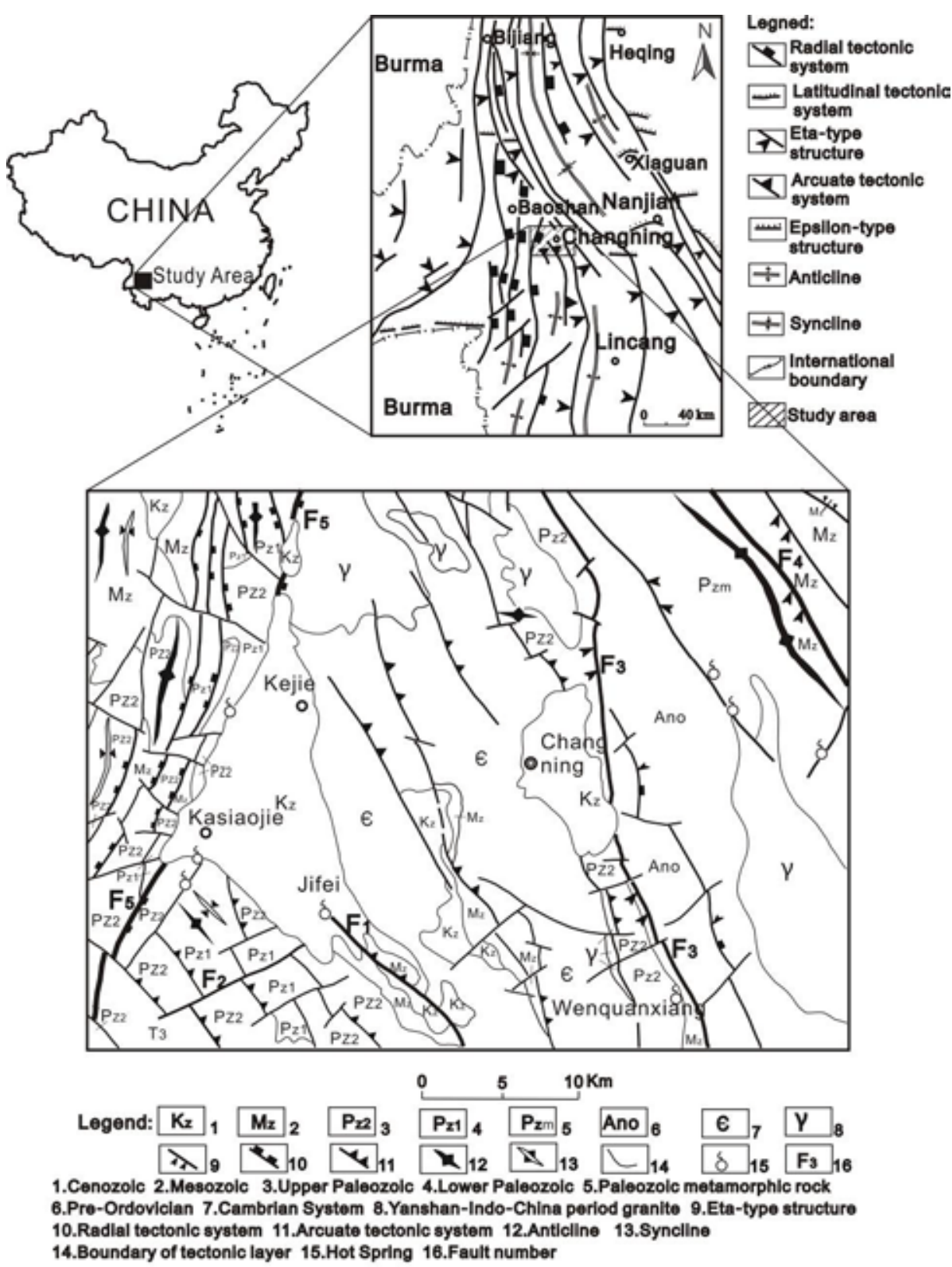

3 Fig. 1 Schematic diagram of tectonic systems (after Geological Bureau of Yunnan Province 1980 and Chinese People’s Liberation Army 1980)

5 Here the Eta-type structure is a part of the Qinghai-Tibet-Yunnan Burma Indonesia eta type

6 structure which is shaped as Greek letter "Eta”. The Epsilon-type structure is the structure

7 which is shaped as Greek letter "Epsilon” 


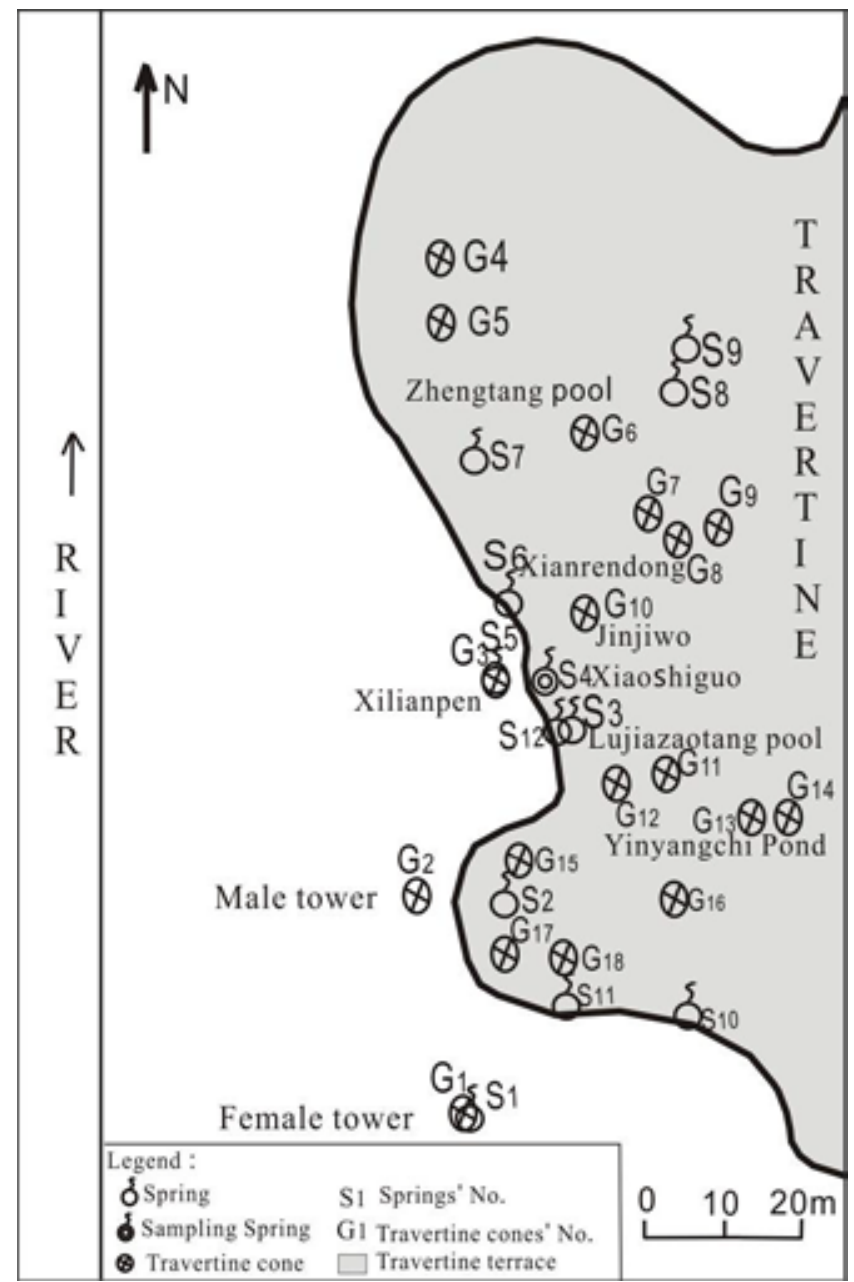

Fig. 2 Sketch map of locations of springs and travertine cones of the Jifei hot spring

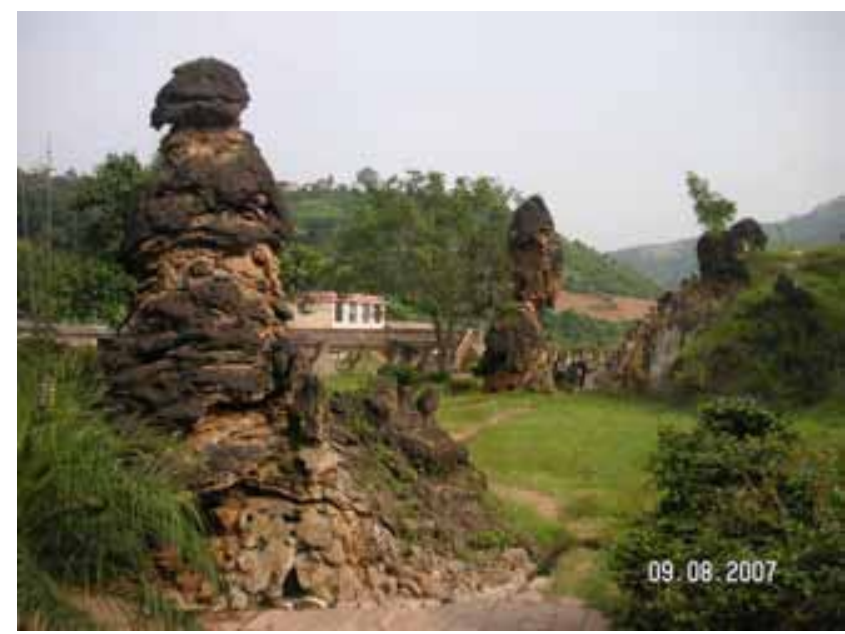

Fig. 3 Male tower (far) and Female tower (near) travertine cones 


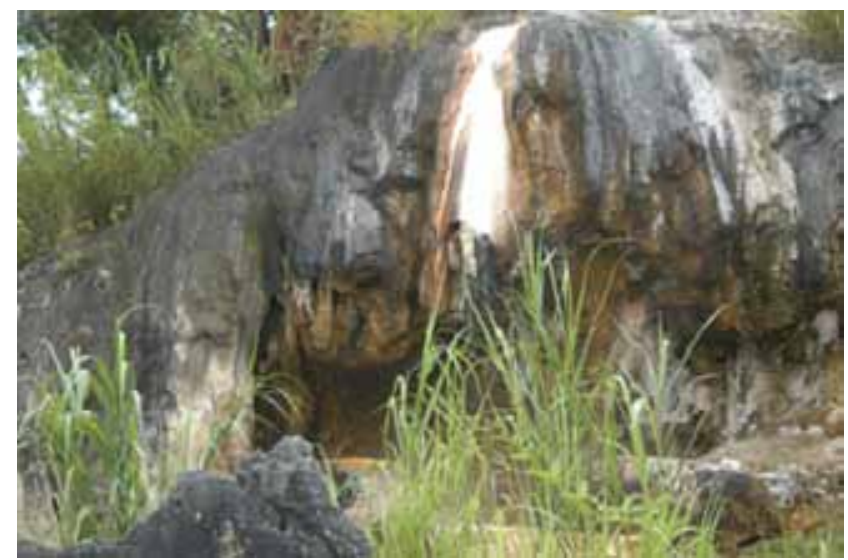

Fig. 4 New travertine (white part), nearby Zhengtang pool spring $\left(S_{7}\right.$ in Fig. 1)

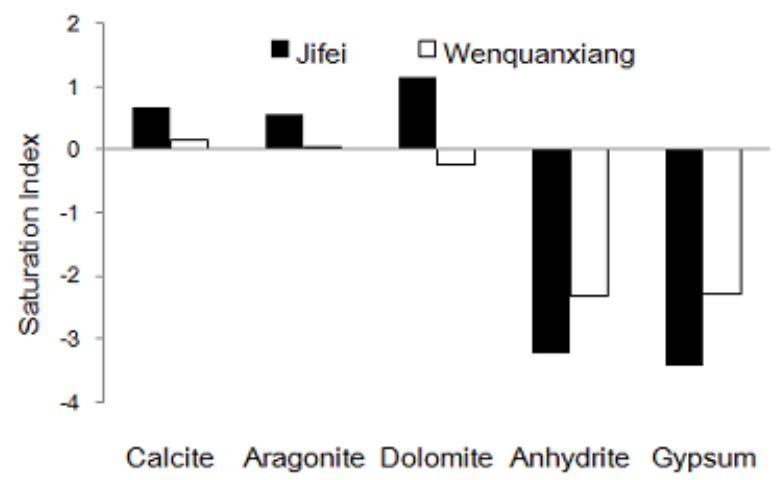

4

Fig. 5 Saturation index diagram of five minerals for the Jifei hot spring and the Wenquanxing 6 hot spring

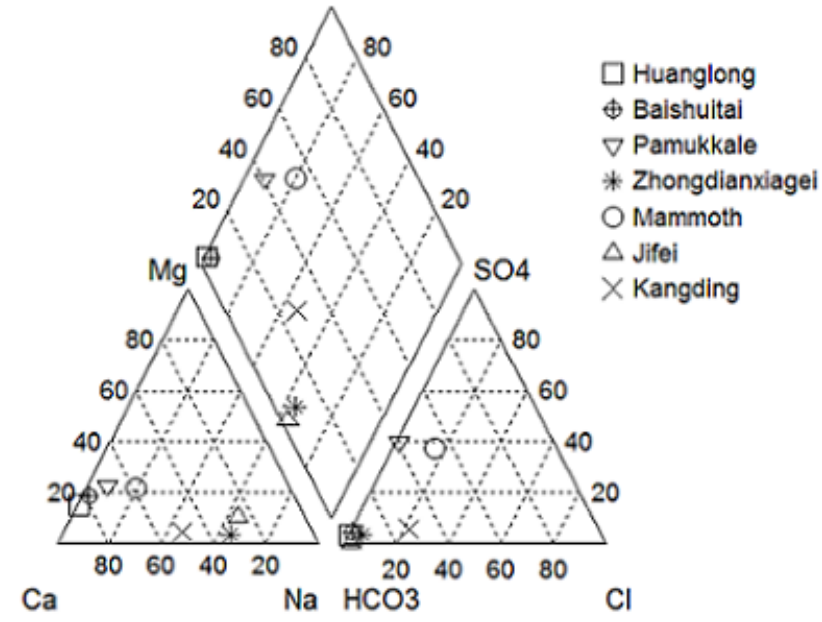

Fig.6 Piper diagram of travertine springs 


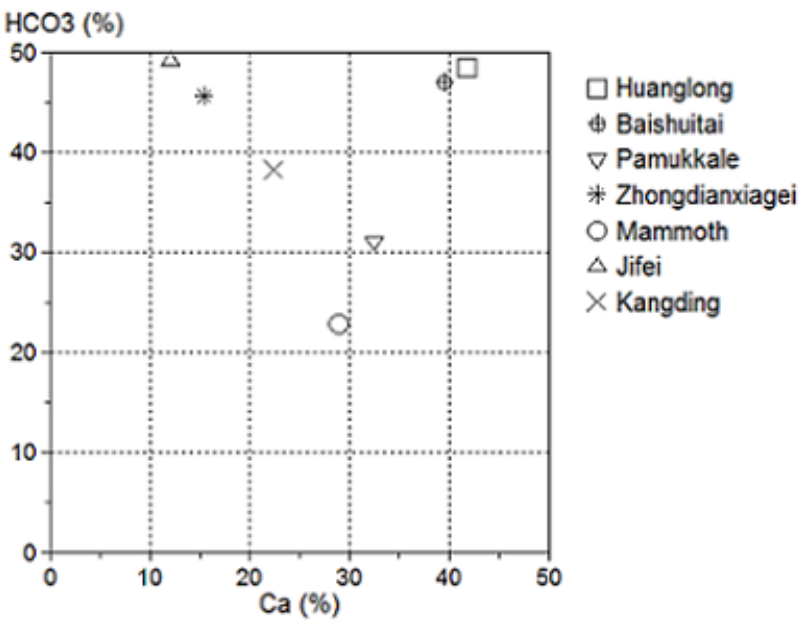

2 Fig. 7 Diagram of milligram equivalent percentage of $\mathrm{Ca}^{2+}$ and $\mathrm{HCO}_{3}{ }^{-}$(equivalent to sum of cations or anions)

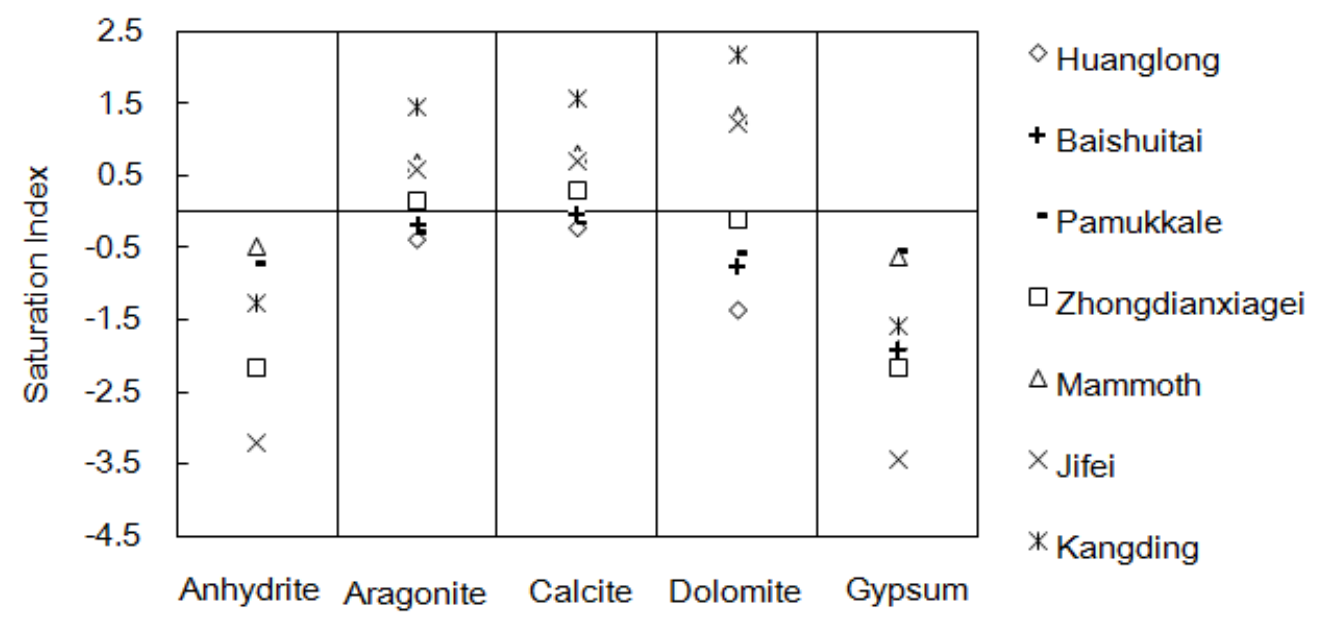

4

Table 1 Hydrochemical compositions (concentrations in mg/L) and isotopic compositions

\begin{tabular}{ccccccccccccc}
\hline Items & $\mathrm{T}\left({ }^{\circ} \mathrm{C}\right)$ & $\mathrm{K}^{+}$ & $\mathrm{Na}^{+}$ & $\mathrm{Ca}^{2+}$ & $\mathrm{Mg}^{2+}$ & $\mathrm{HCO}_{3}{ }^{-}$ & $\mathrm{Cl}^{-}$ & $\mathrm{SO}_{4}{ }^{2-}$ & $\begin{array}{c}\text { Free } \\
\mathrm{CO}_{2}\end{array}$ & $\mathrm{pH}$ & $\mathrm{TDS}$ & $\delta^{13} \mathrm{C}_{\mathrm{DIC}}{ }^{\mathrm{a}}(\%)$ \\
\hline $\begin{array}{c}\text { The Jifei hot spring } \\
\begin{array}{c}\text { The Wenquanxiang hot } \\
\text { spring }\end{array}\end{array}$ & 79.0 & 20.0 & 168.0 & 58.1 & 14.2 & 714.0 & 9.6 & 2.0 & 35.2 & 7.0 & 993.0 & -7.6 \\
& 54.8 & 8.89 & 131.0 & 56.1 & 4.9 & 458.0 & 17.6 & 45.2 & 8.8 & 7.4 & 832.0 & -10.8 \\
\hline
\end{tabular}

9

${ }^{\mathrm{a}} \mathrm{DIC}$ is dissolved inorganic carobon

10

11 
Table 2 Hydrochemical and isotopical data of seven famous travertine springs

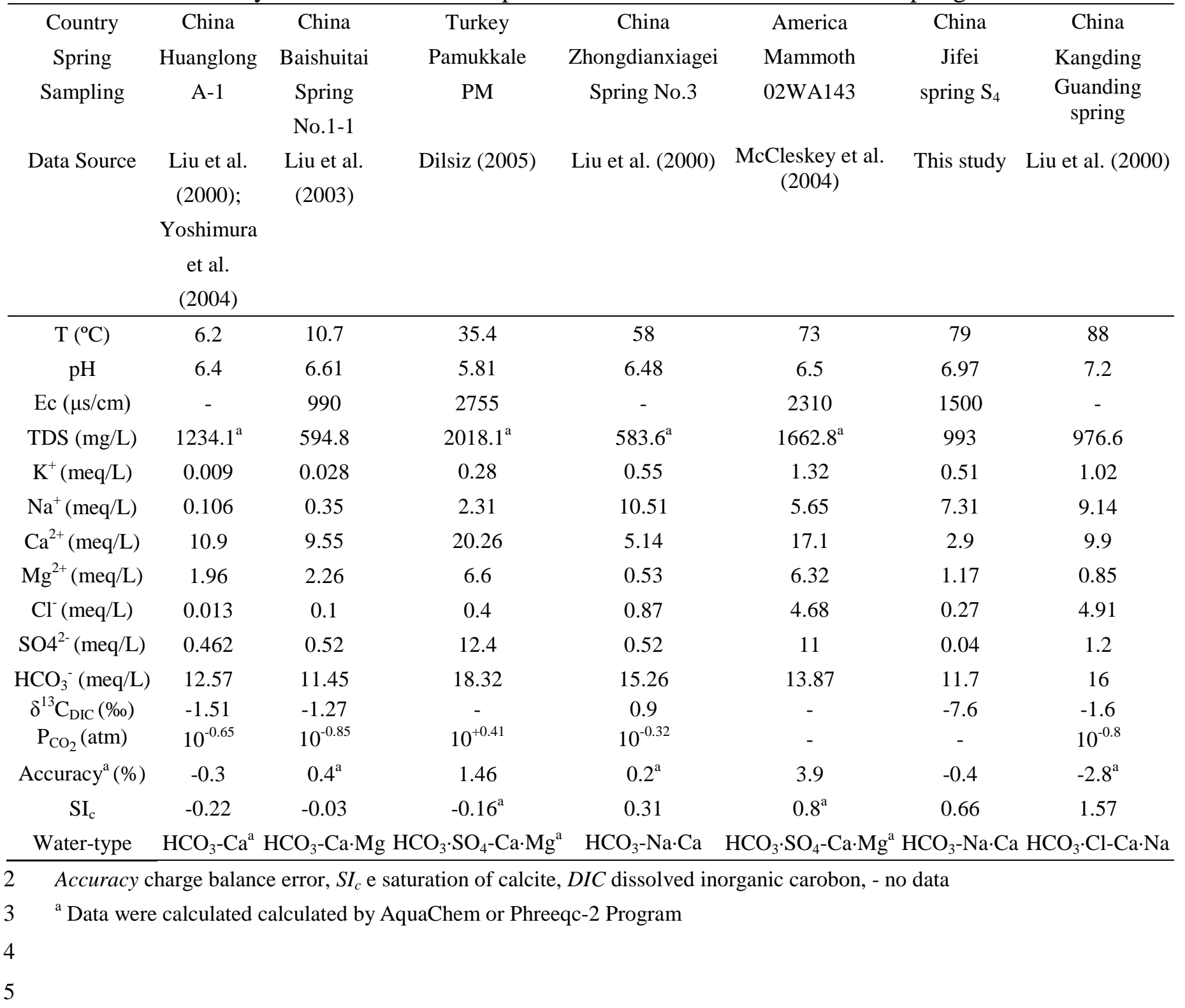

